\title{
A RISK BASED APPROACH TO HERITAGE MANAGEMENT IN SOUTH AFRICA.
}

\author{
C.Jackson ${ }^{a}$, L.Mofutsanyana ${ }^{\mathrm{a},}$, N.Mlungwana ${ }^{\mathrm{a}}$
}

a South African Heritage Resources Agency, 111 Harrington Street Cape Town 8000, South Africa - nmlungwana@sahra.org.za, cjackson@sahra.org.za, lmofutsanyana@sahra.org.za

\section{Commission II, WG II/8}

KEY WORDS: Digital Inventories, Heritage Management, South Africa, SAHRIS, Risk Analysis

\begin{abstract}
:
The management of heritage resources within the South African context is governed by the National Heritage Resources Act, act 25 of 1999 (NHRA). This legislation calls for an integrated system of heritage management that allows for the good governance of heritage across the three tiers of government. The South African Heritage Resources Agency (SAHRA), as the national body responsible for heritage management, is mandated to compile and maintain an inventory of the national estate. The South African Heritage Resources Information System (SAHRIS) was designed to facilitate this mandate as well as provide a management platform through which the three-tiers of governance can be integrated. This vision of integrated management is however predicated on the implementation of the three-tier system of heritage management, a system which to date has not been fully implemented, with financial and human resource constraints being present at all levels. In the absence of the full implementation of this system and the limited resources available to heritage authorities, we argue that a risk based approach to heritage management will allow under resourced heritage authorities in South Africa to prioritise management actions and ensure mitigations are in place for at risk heritage resources. The aim of this paper is to position the inventory of the national estate as the key driver in the production of risk analysis models for an informed approach to heritage management.
\end{abstract}

\section{INTRODUCTION}

Heritage resources management in South Africa is governed by the National Heritage Resources Act, Act 25 of 1999 (NHRA). This new legislation aimed to address the many imbalances in the representation and management of South Africa's heritage postapartheid. Drawing on the principles established by the World Heritage Convention, the Burra Charter, and legislation enacted by countries such as the United Kingdom, Australia, New Zealand and Canada, the NHRA set out to introduce a system of heritage management that is reflective of South Africa's constitution, and integrates the three tiers of government for the benefit of all South Africans (Deacon, 2015).

The NHRA came into effect on 1 April 2000 when the previous heritage management body, the National Monuments Council (NMC) was replaced by the South African Heritage Resources Agency (SAHRA) as the body responsible for heritage management at national level (Deacon, 2015).

Amongst the responsibilities incumbent on SAHRA as the national body for heritage management, is the compilation of a database of protected heritage resources in the country, known as the inventory of the national estate. Annually SAHRA uses the data within the inventory to produce a summary and analysis of the national estate, a document aimed at highlighting trends and making use of the data collected to actively illustrate the importance of inventories in active heritage management (SAHRA, 2017, 2018, 2019).

Inventories of heritage resources are a vital tool for heritage management, as one cannot protect that which is unknown. The importance of inventories as it pertains to the management of risk is a well ingrained concept within international discourse

\footnotetext{
${ }^{1}$ Section 7(1a), National Heritage Resources Act, Act 25 of 1999
}

(Meyers, 2016). As part of the annual summary and analysis SAHRA aimed to illustrate the use of the inventory as a tool to identify risks affecting the preservation of heritage resources so that they may be proactively addressed (SAHRA, 2019).

Noting that the integrated system of heritage management as required under the NHRA is not fully implemented, we argue that the use of a risk-based approach will provide a method through which the three tiers of heritage management authorities can proactively prioritise interventions despite limited resources.

\section{THE THREE TIER SYSTEM}

\subsection{An Integrated and Interactive System of Management}

The three-tier system of heritage management established by the NHRA, provides for implementation of an integrated and interactive system of heritage management where the management of heritage resources is placed within a level of the South African governance structure appropriate to the significance a particular heritage resource holds.

- The South African Heritage Resources Agency (SAHRA), is responsible for the identification, protection, and management of heritage resources whose qualities are of national significance (Grade I) ${ }^{1}$.

- Provincial Heritage Resources Authorities (PHRA's) are responsible for resources which are significant within the context of a specific province of region $(\text { Grade II) })^{2}$. 
- Local authorities are responsible for other conservation worthy resources which do not fulfil the criteria for national or provincial significance (Grade III) ${ }^{3}$.

Though it has been 19 years since the effecting of the NHRA, many of the lofty goals of this legislation remain unfulfilled. Chief amongst these being the implementation of the three-tier system of heritage management (Deacon, 2015; Ndlovu, 2011).

\subsection{A System in Crisis}

Ideally, after the promulgation of the NHRA, the heritage management system was aimed at following a bottom-up approach based on the level of significance. This integrated and interactive approach is predicated on the establishment of the provincial and local authorities. The idea was centred on equipping each tier governance structure with the authority of heritage conservation and decision-making. However, the NHRA was not costed prior to its enactment, resulting in an unfunded mandate being placed upon the provinces (Deacon, 2015)

Section 23 of the NHRA is the enabling provision for the establishment of PHRAs, however this provision states that the Provincial Member of the Executive Committee (MEC) responsible for cultural matters "may" establish a PHRA. This wording implies that the establishment of a PHRA is not mandatory.

This unfortunate wording and the lack of funding available to fulfil this mandate has resulted in most of the provincial authorities being under capacitated and underfunded (Deacon, 2015).

2.2.1 Devolution and Competency: Under section $8(6 a)$ of the NHRA, provincial or local authorities shall not undertake any action under the national legislation (or provincial legislation where such exists) unless it is deemed competent to do so (Department of Arts and Culture, 1999).

The devolution process follows the three tiers in that it is the responsibility of SAHRA to assess the competency of PHRA's, and in turn it is incumbent on the PHRA's to access the competency of the local authorities.

To begin this process, SAHRA developed a rudimentary set of regulations through which to assess the competency of PHRAs. Smuts and Wiltshire (2016) note that these regulations were based on the resources provided to the provincial offices of SAHRA's predecessor, the NMC. Whilst some work has been undertaken within SAHRA to revise these regulations, there is no clear timeframe for when this process will conclude.

Despite being minimal in nature, these requirements are used to assess the competence the PHRA's. To date only three PHRA's, out of nine, are deemed fully competent to fulfil all functions mandated to them under the NHRA (Table 2-1).

Within these provinces a few municipalities are striving to take on the role of the local authority as envisaged in the NHRA, with work being undertaken for many years by Heritage Western Cape to devolve powers to the City of Cape Town, and the Drakenstein Municipality noting in their Integrated Development Plan (IDP) that devolution of powers will be sought (Drakenstein Municipality, 2019; HWC, 2014, 2015, 2016, 2017). It has been further noted that whilst the North West Provincial Heritage Resources Authority is not fully competent, they have begun the processes to start engaging with municipalities regarding devolution in the North West Province (NWPHRA, 2019).

The strides taken to devolve powers to local authorities is commendable, however with 278 municipalities in South Africa, there is still quite some way to go.

\begin{tabular}{|l|l|}
\hline Province & Competence \\
\hline KwaZulu-Natal & Full Competence \\
\hline Eastern Cape & Full Competence \\
\hline Gauteng & Partial Competence \\
\hline Northern Cape & Partial Competence \\
\hline Western Cape & Full Competence \\
\hline Limpopo & Partial Competence \\
\hline Mpumalanga & Partial Competence \\
\hline North West & Partial Competence \\
\hline Free State & Partial Competence \\
\hline
\end{tabular}

Much can be said about the assessment criteria, however one alarming take away is that despite the minimal nature of the requirements, only three PHRA's comply with them. It is also important to note that whilst the above table notes the technical competence of the PHRA's it does not address practical competence, nor does it unpack greater concerns such as the required legal standing of the PHRA's as body corporates (Prins, 2016), or whether the assessments occur within legislated timeframes. These are topics that require a great deal of interrogation in future papers.

\section{THE INVENTORY OF THE NATIONAL ESTATE}

\subsection{The Inventory and SAHRA's Mandate}

The value of heritage inventories is enshrined within numerous international conventions and recommendations (Meyers, 2016). As the NHRA drew from international best practice in its formulation, the importance of an inventory of heritage resources is legislatively enshrined within South Africa.

Section 39 of the NHRA expressly mandates SAHRA to build and maintain a database of all protected or otherwise conservation worthy heritage resources in South Africa, no matter the level at which they are managed. Furthermore this section enshrines the right of the South African public to have access to this information, noting that access may be restricted should the public availability of information negatively impact on any person's economic interests, privacy, or on the conservation of the heritage resource (Department of Arts and Culture, 1999).

\subsection{The South African Heritage Resources Information System}

To fulfil the mandate of an inventory of the national estate, SAHRA developed the South African Heritage Resources Information System (SAHRIS). A system designed for complete

\footnotetext{
${ }^{3}$ Section 7(1c), National Heritage Resources Act, Act 25 of 1999
} 
heritage management and to integrate the functions of all three tiers of government into a singular portal (Wiltshire, 2013).

The system functions as a collections management platform for objects, a heritage sites repository, and an integrated applications management system which enables resources to be recorded and managed whether they are of national provincial or local significance (Wiltshire, 2013).

The datasets used to populate the inventory come from a variety of sources, such as surveys, historical sources, heritage impact assessments, permit applications, and databases held by SAHRA's predecessor organisations.

\subsection{Annual Summary and Analysis of the National Estate}

As SAHRA continues to compile and maintain the inventory of the national estate, it is also a requirement that at regular intervals a summary and analysis of the national estate is published.

This report utilises the information recorded on SAHRIS to present a simplified view of the inventory as well as identify any gaps within the inventory. Furthermore, this publication has been used as a platform to illustrate the importance of an inventory for active heritage management.

Thus far this report has been published three times, each with its own particular focus.

- 2016 Report: Baseline for numbers of formally protected resources,

- 2017 Report: Updating of the baseline and illustrating the importance of inventories for development planning

- 2018 Report: Updating of the baseline and illustrating the importance of inventories in risk management

\subsection{Challenges with Inventory Management and the Three Tier System}

It is imperative for the three-tier system to work for the intention of the inventory of the national estate to be fruitful, to ensure that these sites are accurately recorded, and to ensure that the data is still relevant.

Noting the current state of the three-tier system it has proven challenging to ensure accuracy and relevancy of datasets.

Annually each PHRA is requested to verify the database of formally protected heritage sites within their respective provinces, to ensure that any new formal protections or losses of heritage sites are recorded. This process has largely been a paperbased exercise due to the inability of the PHRA's to perform proper verifications (SAHRA, 2018). In most cases no response is received. This poses a risk in terms of the accuracy and relevancy of information presented through these reports.

The roll out of SAHRIS for use by the PHRA's highlighted several issues hindering the ability of the PHRA's to successfully manage the heritage resources within their remit, these include a lack of staff, governance and funding (Smuts \& Wiltshire, 2016).

In preparation for this paper a call was sent to each provincial authority to provide an update on the data presented by Smuts and Wiltshire in 2016; and to gather further information regarding risks to heritage resources as they see them as well as the progress of assessing the competency of local authorities.

The information requested is as follows;

1. Staffing and staff skill sets,

2. Organisational budget and the portion used specifically for heritage operations,

3. Status of competency assessments of local authorities (municipalities),

4. What risks are affecting heritage resources within the province,

5. What is the progress of populating heritage registers and what challenges the PHRA is experiencing that may prevent this?

At the time of writing, only one PHRA had responded to this request for information.

In the absence of new data, the status quo as set by Smuts and Wiltshire (2016) largely remains, though with the exception of the North West Provincial Heritage Resources Authority which was the only PHRA to respond, and where engagements with the PHRA has provided additional insight (Table 3-1).

This lack of response highlights one of the key issues facing SAHRA, namely the lack of communication between the authorities. In fact, during an engagement with one authority, they noted that some of the information requested is confidential. A statement that raises greater concerns considering that the PHRA's are publicly funded entities and are subject to public scrutiny.

\begin{tabular}{|c|c|c|c|c|}
\hline PHRA & Staff & Skills & Funding & Source \\
\hline $\begin{array}{l}\text { KwaZulu- } \\
\text { Natal }\end{array}$ & $20-30$ & $\begin{array}{l}\text { Admin, } \\
\text { Archaeology, } \\
\text { Palaeontology } \\
\text {, Built } \\
\text { Environment, } \\
\text { GIS }\end{array}$ & & $\begin{array}{l}\text { Smuts \& } \\
\text { Wiltshire } \\
\text { (2016) }\end{array}$ \\
\hline $\begin{array}{l}\text { Eastern } \\
\text { Cape }\end{array}$ & $3-5$ & $\begin{array}{l}\text { Built } \\
\text { Environment, } \\
\text { Archaeology }\end{array}$ & & $\begin{array}{l}\text { Smuts \& } \\
\text { Wiltshire } \\
\text { (2016) } \\
\end{array}$ \\
\hline Gauteng & $5-10$ & $\begin{array}{l}\text { Admin, Built } \\
\text { Environment }\end{array}$ & & $\begin{array}{l}\text { Smuts \& } \\
\text { Wiltshire } \\
\text { (2016) }\end{array}$ \\
\hline $\begin{array}{l}\text { Northern } \\
\text { Cape }\end{array}$ & 2 & $\begin{array}{l}\text { Admin, Built } \\
\text { Environment }\end{array}$ & & $\begin{array}{l}\text { Smuts \& } \\
\text { Wiltshire } \\
\text { (2016) }\end{array}$ \\
\hline $\begin{array}{l}\text { Western } \\
\text { Cape }\end{array}$ & $\begin{array}{l}10-20 \\
(5 \\
\text { Officer } \\
\text { s) }\end{array}$ & $\begin{array}{l}\text { Admin, } \\
\text { Archaeology, } \\
\text { Palaeontology } \\
\text {, Built } \\
\text { Environment }\end{array}$ & & $\begin{array}{l}\text { Smuts \& } \\
\text { Wiltshire } \\
\text { (2016), } \\
\text { DCAS } \\
\text { (2018) }\end{array}$ \\
\hline Limpopo & 3-5 & $\begin{array}{l}\text { Admin, Built } \\
\text { Environment }\end{array}$ & & $\begin{array}{l}\text { Smuts \& } \\
\text { Wiltshire } \\
\text { (2016) } \\
\end{array}$ \\
\hline $\begin{array}{l}\text { Mpumalang } \\
\text { a }\end{array}$ & 2 & $\begin{array}{l}\text { Admin, Built } \\
\text { Environment }\end{array}$ & & $\begin{array}{l}\text { Smuts \& } \\
\text { Wiltshire } \\
\text { (2016) }\end{array}$ \\
\hline North West & 3 & $\begin{array}{l}\text { Heritage } \\
\text { Management, } \\
\text { GIS, } \\
\text { Indigenous } \\
\text { Knowledge } \\
\text { Systems, } \\
\text { Built } \\
\text { Environment, } \\
\text { History, } \\
\text { Research }\end{array}$ & & $\begin{array}{l}\text { NWPHRA } \\
\text { (2019) }\end{array}$ \\
\hline
\end{tabular}




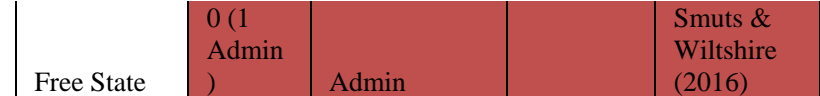

Table 3-1: Comparative representation of PHRA resources. Colour code is rated from worst (Red), to best (Green). Adapted from Smuts and Wiltshire (2016).

It should be noted that table 3-1 above, does not indicate whether the resources and skills are sufficient, but is rather a comparison between PHRA's.

Further to the above, SAHRA is also responsible for the establishment and funding of a South African Heritage Resources Survey under section 13(2c) of the NHRA. A mandate that SAHRA is unable to fulfil at this stage.

Despite these issues, some authorities, such as those in the Western Cape have supported or undertaken identification projects.

It should also be noted that historically numerous built environment surveys have been undertaken in South Africa, however a lack of institutional memory has resulted in these being relegated to library shelves and archival boxes. SAHRA is undertaking a process to identify these in order to incorporate them into the national inventory.

The North West Provincial Authority has also noted that they are supported by their mother department and other bodies with the provision of information, however a shortage of staff prevents large scale undertakings (NWPHRA, 2019).

It is apparent that despite the legal requirements for inventories, the importance of inventories needs to be illustrated. It is in this vein that the annual summary and analysis has been used as a platform to illustrate the importance of inventories.

\section{RISK MANAGEMENT}

\subsection{Why a risk management approach}

Heritage management is often an under resourced field. Heritage managers often need to prioritise interventions in order to best allocate available financial resources and human capital for the preservation of heritage resources (ICCROM, 2016).

As has been illustrated in the preceding discussions, this is true of South Africa. The entrenched under resourcing of heritage authorities results in a system based on reaction rather than proactive intervention. The 2016 ICCROM Guide to Risk Management of Cultural Heritage notes that risk management can be a tool to make better decisions concerning the prioritisation of interventions for conservation (ICCROM, 2016). Thus, using this approach can be beneficial to the overall management of heritage resources in South Africa.

The identification of risk and the prioritisation of intervention should be based on a level of data analysis to assist with the identification and likelihood of a risk affecting a resource. Furthermore, heritage resources are not only at risk from potential hazards, but also from a lack of preparedness for response to occurrences and their rehabilitation post occurrence (Jigyasu, 2005).

Following a series of fires in the Western Cape Province that directly impacted a National Heritage Site (figures $1 \& 2$ ), and a number of Provincial heritage resources (see Charles, 2019; de
Villiers, 2017), it was decided to use the summary and analysis of the national estate to illustrate the importance of comprehensively recorded resources and disaster management planning.

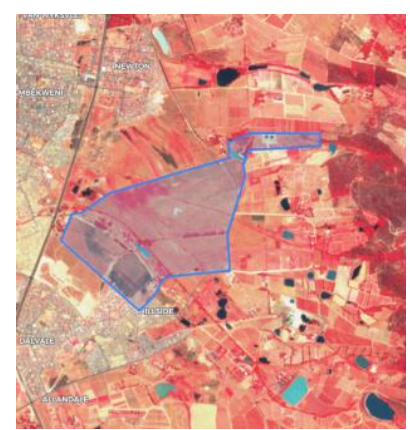

Figure 1: The Dal Josafat Cultural Landscape in 2016 before fire (Modified

Copernicus Sentinel data, 2016/Sentinel Hub)

\subsection{Defining risk}

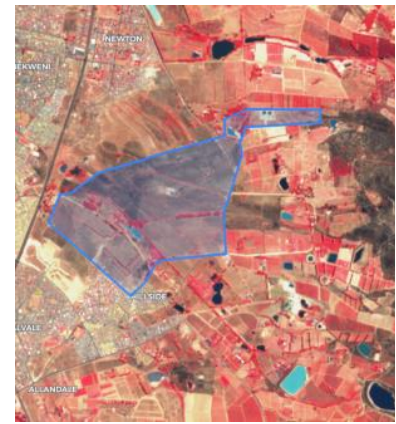

Figure 2: The Dal Josafat Cultural Landscape in 2017, post fire, burn scars are

shown as black areas

(Modified Copernicus Sentinel data, 2017/Sentinel Hub).
Risks come in many forms, some natural, such as fire and seismic activity, or anthropogenic, such as vandalism and the uncontrolled encroachment of development. The identification and acknowledgement of these risks will allow for mitigating plans to be implemented in order to retain the significance of an affected heritage resource (UNESCO, 2010).

\subsection{Inventories and risk management}

Heritage inventories are the basis for all aspects of heritage management as one cannot manage and protect what is not known. Noting this, the availability of information on identified heritage resources is vital in the identification and management of potential risk. Ensuring that this information is available to decision making bodies is vital in ensuring that heritage is not placed at risk due to a lack of information (Meyers, 2016).

\subsection{What are we doing?}

The operationalisation of the inventory of the national estate as a tool for active risk identification and management at this stage is in its infancy. The need to illustrate the importance of inventories resulted in the first steps being taken towards actively identifying risks affecting heritage resources in South Africa.

Bodies within the country, such as the Council for Geoscience (CGS), South African National Space Agency (SANSA), and the Council for Scientific and Industrial Research (CSIR) have been actively producing data at a national scale pertaining to risk (see Brandt, 2011; Forsyth et al. 2010; SANSA, 2015). This data was incorporated into the existing body data within the inventory of the national estate in order to identify heritage places that fall within the areas of risk identified by the afore mentioned bodies.

Due to the limited timeframes inherent in the production of the annual summary and analysis only certain risk themes were analysed, these being;

1. Veldfire susceptibility

2. Seismic susceptibility

3. Flood risk 


\section{Uncontrolled development}

\subsection{Findings and Limitations}

4.5.1 Veldfire: The CSIR, in 2010, produced a national veldfire risk report that identifies areas of risk in South Africa (Forsyth et al. 2010).

Combining the veldfire risk data (Forsyth et al. 2010), with our own database of formally protected National and Provincial Heritage Sites (figure 3 ) shows that $58.39 \%$ of National Heritage Sites (NHS) fall within areas of extreme risk, and $64.05 \%$ of Provincial Heritage Sites (PHS) fall within areas of extreme to high risk. This assessment is based on very high-level data and does not account for resources in urban settings or the type of resource affected. It does however illustrate the need to be cognisant of this risk in management planning for their conservation. A more nuanced approach to this will be to seek data from the provincial risk management bodies which will provide a more accurate presentation of the risk.

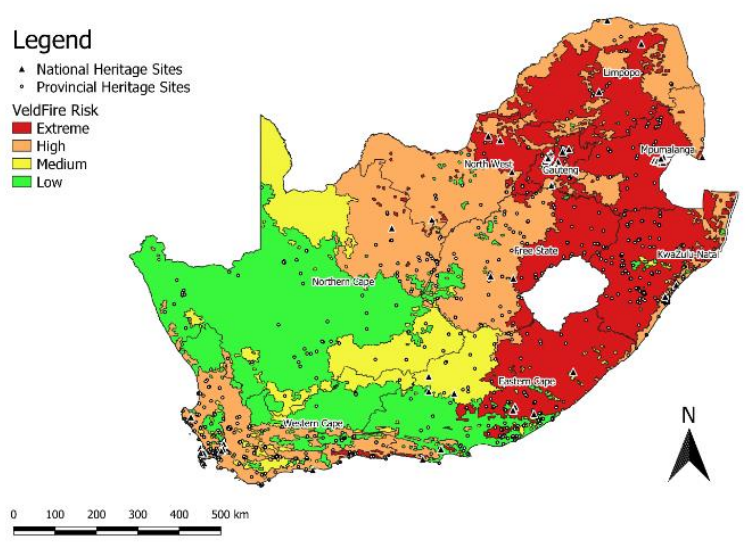

Figure 3: Map showing National and Provincial Heritage Sites in relation to identified VeldFire risk (SAHRA, 2019)

4.5.2 Seismic susceptibility: South Africa is rated moderate to low in terms of seismicity due to the relatively stable African crust, however South Africa does experience a scatter of seismic foci with a wide range of intensities as measured on the Modified Mercalli Scale (MMS). These occurrences are the result of both natural geomorphic processes and anthropogenic factors such as mining (Brandt, 2011).

Figure 4 below presents these seismic intensities (Council for Geoscience, 2015) in relation to the locations of NHS's and PHS's.

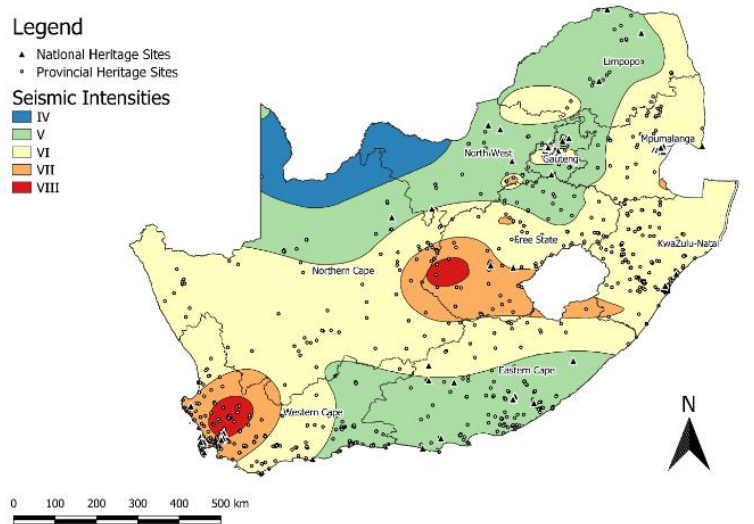

Figure 4: Map showing National and Provincial Heritage Sites in relation to identified seismic intensity risk areas (SAHRA, 2019)

From this analysis we can determine that $60 \%$ of all NHS's fall within regions of strong to severe (VI-VIII) regions of seismic intensity. 70\% of PHS's are found within areas of strong to severe intensity (SAHRA, 2019).

\begin{tabular}{|l|l|l|}
\hline $\begin{array}{l}\text { Intensity } \\
\text { Level }\end{array}$ & Shaking & Description \\
\hline IV & Light & $\begin{array}{l}\text { Light tremors; No structural } \\
\text { movement }\end{array}$ \\
\hline V & Moderate & $\begin{array}{l}\text { Movement of unstable structures and } \\
\text { objects }\end{array}$ \\
\hline VI & Strong & $\begin{array}{l}\text { Structural movement with slight } \\
\text { damage }\end{array}$ \\
\hline VII & $\begin{array}{l}\text { Very } \\
\text { Strong }\end{array}$ & $\begin{array}{l}\text { Structural movement; considerate } \\
\text { damage to fragile structures }\end{array}$ \\
\hline VIII & Severe & $\begin{array}{l}\text { Structural movements; great damage } \\
\text { to fragile structures; major damage to } \\
\text { stack structures including } \\
\text { monuments }\end{array}$ \\
\hline
\end{tabular}

Table 4-1: Adapted Modified Mercalli Intensity Scale (USGS, 2019).

According to the MMS, seismic intensities within the moderate to severe range can induce secondary hazards such as landslides and rockfalls. Based on this high-level analysis it can be concluded that $75 \%$ of all declared heritage resources reside in areas that exhibit seismic risk.

This analysis can be further refined through greater research into the resources within high risk areas in order to account for variables such as resources type and construction materials (SAHRA, 2019).

4.5.3 Flood risk: Flood risk is considered to be one of the largest natural risks facing heritage resources globally (Bedeaux et al. 2018).

The South African National Space Agency (SANSA) has developed a potential flood map using the Height Above Nearest Drainage (HAND) product, which uses river channels as a zero point for elevation. This map provides an indication of areas that 
will be inundated when water level rises by 1, 3 and 5 meters above the river channel (SANSA, 2015).

The overwhelming majority of site location data stored within the national inventory is point based. In order to account for this a 100 meter buffer was placed on all heritage resources to provide for an area of potential intersection with the flood risk spatial layer (SAHRA, 2019).

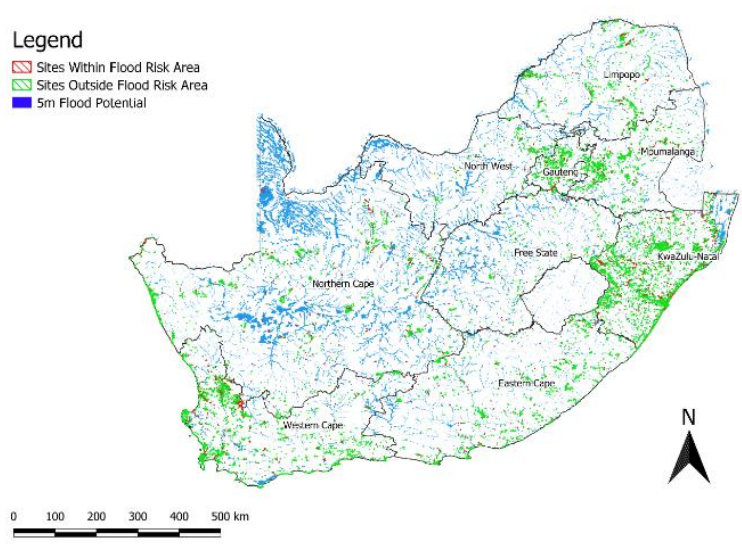

Figure 5: 5 Meter flood risk analysis (SAHRA, 2019)

Based on the 5 meter flood projection, $11.78 \%$ of all generally and formally protected resources are at risk of being impacted by flood from river channels (SAHRA, 2019).

As more information becomes available regarding the actual boundaries of these resources, this data can be improved.

4.5.4 Uncontrolled development: Very little information currently exists regarding developments that have been undertaken without the required heritage approvals. SANSA has however produced a spatial dataset pertaining to informal settlements in 48 key municipalities (SANSA, 2015).

The primary dataset used for this analysis was last updated in 2011, with the Western Cape portion being updated in 2016, which presents the risk of using outdated data to establish whether any known resources are at risk from expanding informal settlement. In order to counter this and account for possible growth, a 1 kilometre buffer was added to the informal settlements dataset.

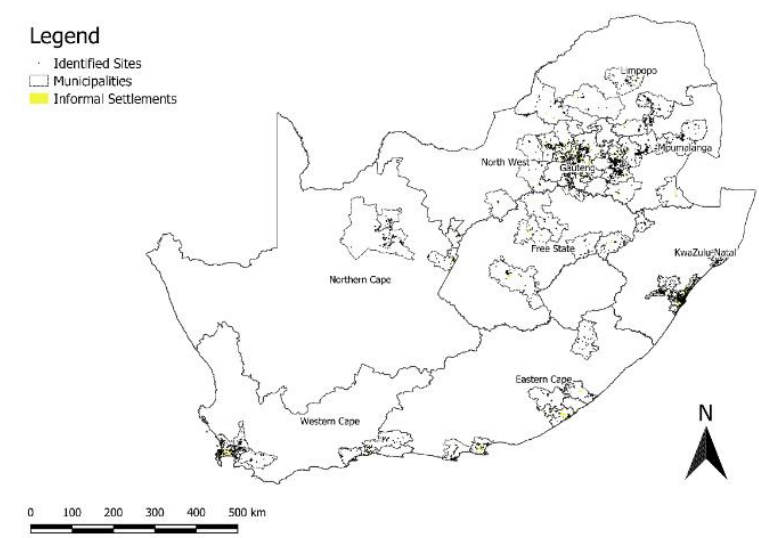

Figure 6: Heritage resources within $1 \mathrm{~km}$ of informal settlements (SAHRA, 2019)
Only known heritage resources within the 48 municipalities were included in this analysis. The results of this analysis showed that $6.27 \%$ of known resources are within a $1 \mathrm{~km}$ radius of the mapped informal settlements. As this analysis is based on identified resources, the low percentage of known resources at risk of being impacted by informal development is unsurprising considering that that traditional impact assessment protocols would not have been undertaken as expansion takes place.

\subsection{Way forward}

The analysis undertaken above is still rudimentary, and at this stage only illustrates the existence of risks potentially affecting South Africa's heritage resources. As this project was undertaken in a relatively informal manner as part of a larger report it did not allow for sufficient resource allocation to be made to expand upon the data.

This undertaking does lay the foundation for further work which can incorporate more nuanced data to produce a national risk assessment model for the country. The first step in this process will be the formalisation of this project and further investigation into similar undertakings globally. The work undertaken in Italy under the Istituto Centrale per il Restauro (ICR) provides a potential model which can be used to guide this process (UNSECO, 2010; Accardo et al. 2003).

Moreover, the use of this data can lay the foundation for a strategy to prioritise management intervention for the most atrisk resources, thereby allowing heritage to still be protected despite the limited human and financial capital available to heritage authorities.

\section{CONCLUSION}

The work undertaken thus far is still exploratory in nature, though it does serve to highlight the importance of risk management in respect to the conservation of heritage resources. Having outlined some of the issues facing heritage management in South Africa, we feel that inculcating a risk-based approach to the management of heritage in the country will provide a mechanism to allow competent authorities to prioritise management interventions using an approach informed by data analysis. Whilst this approach will not solve the institutional problems encountered in South Africa, it does have the potential provide the groundwork for proactive management.

\section{REFERENCES}

Accardo, G., Giani, E., \& Giovagnoli, A., 2003. The Risk Map of Italian Cultural Heritage. Journal of Architectural Conservation, 9(2), pp. 41-57.

Bedeaux, D.G., Amsing, E.B.J., van 't Wout., T. Augustyn, A.M., 2018. Is cultural heritage life saving? Case study analysis to the relation between flood risk management and cultural heritage. IAIA18 Conference Proceedings. Environmental Justice in Societies in Transition. In: 38th Annual Conference of the International Association for Impact Assessment, 16-19 May 2018. Durban, South Africa.

Brandt, M., 2011. Seismic Hazard in South Africa. In: Council for GeoScience Report. Report no.: 2011-0061, Bellville, Cape Town, South Africa, pp. 1-21. 
Council for GeoScience, 2015. South African Geological Hazards Observation System Atlas. Council for Geoscience, Pretoria, South Africa. http://www.geoscience.org.za/index.php/home-saghos\# March 2019)

Charles, M., 2019. Wupperthal buildings can be restored says Heritage Western Cape. https://www.iol.co.za/capeargus/news/wupperthal-buildingscan-be-restored-says-heritage-western-cape-18910454 (27 June 2019).

de Villiers, J., 2017. Western Cape fires under control. NEWS24. https://www.news24.com/SouthAfrica/News/western-capefires-under-control-20170111 (27 June 2019).

Deacon, J., 2015. Great Expectations: Archaeological sites and the National Heritage Resources Act (Act 25 of 1999). The South African Archaeological Bulletin, 70(202), pp. 220-223.

Department of Arts and Culture, South Africa, 1999. National Heritage Resources Act 25 of 1999. Government Gazette, 506(19974), Pretoria, South Africa Government Printers.

Drakenstein Municipality, 2019. 2018/2024 Integrated Development Plan (IDP) - 2019 Review. Drakenstein Municipality, Western Cape, South Africa.http://www.drakenstein.gov.za/docs/Documents/2.\%20I DP\%20Review\%202019\%20-

\%202020\%20Drakenstein\%20IDP_draft.pdf (27 June 2019).

Forsyth, G., Kruger, F., Le Maitre, D., 2010. National veldfire risk assessment: Analysis of Exposure of Social, Economic and Environmental Assets to veldfire Hazards in South Africa. Report CSIR/NRE/ECO/ER/2010/0023/C. CSIR-National Resources and the Environment, South Africa, Pretoria.

Heritage Western Cape, 2014. Heritage Western Cape Annual Report 2013/2014. Cape Town, Western Cape Provincial Government.

Heritage Western Cape, 2015. Heritage Western Cape Annual Report 2014/2015. Cape Town, Western Cape Provincial Government.

Heritage Western Cape, 2016. Heritage Western Cape Annual Report 2015/2016. Cape Town, Western Cape Provincial Government.

Heritage Western Cape, 2017. Heritage Western Cape Annual Report 2016/2017. Cape Town, Western Cape Provincial Government.

ICCROM, 2016. A Guide to Risk Management of Cultural Heritage. Government of Canada, Canadian Conservation Institute, pp, 8.

Jigyasu, R., 2005. Towards developing methodology for integrated risk management of cultural heritage sites and their settings. In: 15th ICOMOS General Assembly and International Symposium: Monuments and sites in their setting - conserving cultural heritage in changing townscapes and landscapes, 17 21 Oct 2005, Xi'an, China.

Meyers, D., 2016. Heritage Inventories: Promoting Effectiveness as a Vital Tool for Sustainable Heritage Management. Journal of
Cultural Heritage Management and Sustainable Development, 6(2), pp. 102-112. doi.org/10.1108/JCHMSD-02-2016-0009.

Ndlovu, N., 2011. Legislation as an Instrument in South African Heritage Management: Is It Effective? Conservation and Management of Archaeological Sites, 13(1), pp. 31-57. doi.org/10.1179/175355211X13097877338932.

NWPHRA, 2019. Provincial Inventory Unit Information as requested by National Inventory Office. [email correspondence 24 May 2019].

Prins, H, 2016. The System Has Failed to Achieve its Purpose. The Heritage Portal. http://www.theheritageportal.co.za/article/system-has-failedachieve-its-purpose (27 June 2019).

SAHRA, 2017. Summary and Analysis of the Inventory of the National Estate: 2016. South Africa: Zonnebloem, Cape Town.

SAHRA, 2018. Summary and Analysis of the Inventory of the National Estate: 2017. South Africa: Zonnebloem, Cape Town.

SAHRA, 2019. Summary and Analysis of the Inventory of the National Estate: 2018. South Africa: Zonnebloem, Cape Town.

SANSA, 2015. South African Remote Sensing Atlas. South African National Space Agency http://atlas.sansa.org.za/index.html (27 June 2019).

Sentinel Hub, 2019. Sentinal Hub https://sentinel-hub.com/eobrowser, Version .19.3,, Sinergise Ltd. (27 June 2019).

Smuts, K and Wiltshire, N., 2016. Challenges Facing Heritage Management in South Africa: Implementation of a Web-Based National Heritage Management System. In Sadr, K., Esterhuysen, A. and Sievers, C. (Eds). African Archaeology without Frontiers: Papers from the 2014 PanAfrican Archaeological Association Congress. Johannesburg: Wits University Press, pp. 165-177.

Smuts, K., Mlungwana, N., Wiltshire, N., 2016. SAHRIS: South Africa's integrated, web-based heritage management system. Journal of Cultural Heritage Management and Sustainable Development, 6(2), pp.138152, https://doi.org/10.1108/JCHMSD-01-2016-0002.

Stovel, H., 1998. Risk preparedness: a management manual for world cultural heritage. ICCROM. Retrieved from: http://www.iccrom.org/pdf/ICCROM_17_RiskPreparedness_en .pdf (20 March 2019).

UNESCO, 2010. Managing Disaster Risks for World Heritage. UNESCO, Paris, pp. 1-66.

USGS, 2019. The Modified Mercalli Intensity Scale. In: The Severity of an Earthquake, USGS, U.S. Government Printing Office: 1989-288-913. https://earthquake.usgs.gov/learn/topics/mercalli.php (12 March 2019).

Wiltshire, N., 2013. The use of SAHRIS as a state sponsored digital heritage repository and management system in South Africa. In: ISPRS Annals of the Photogrammetry, Remote Sensing and Spatial Information Sciences, Vol. II-5/W1, pp. 325330, doi.org/10.5194/isprsannals-II-5-W1-325-2013. 